\title{
A novel antibacterial peptide derived from Crocodylus siamensis haemoglobin hydrolysate induces membrane permeabilization causing iron dysregulation, oxidative stress and bacterial death
}

Article

Accepted Version

Lueangsakulthai, J., Jangpromma, N., Temsiripong, T., McKendrick, J. E., Khunkitti, W., Maddocks, S.E. and Klaynongsruang, S. (2017) A novel antibacterial peptide derived from Crocodylus siamensis haemoglobin hydrolysate induces membrane permeabilization causing iron dysregulation, oxidative stress and bacterial death. Journal of Applied Microbiology, 123 (4). pp. 819-831. ISSN 1364-5072 doi: https://doi.org/10.1111/jam.13539 Available at https://centaur.reading.ac.uk/72721/

It is advisable to refer to the publisher's version if you intend to cite from the work. See Guidance on citing.

Published version at: http://dx.doi.org/10.1111/jam. 13539

To link to this article DOI: http://dx.doi.org/10.1111/jam.13539

Publisher: Wiley 
All outputs in CentAUR are protected by Intellectual Property Rights law, including copyright law. Copyright and IPR is retained by the creators or other copyright holders. Terms and conditions for use of this material are defined in the End User Agreement.

\section{www.reading.ac.uk/centaur}

\section{CentAUR}

Central Archive at the University of Reading

Reading's research outputs online 

permeabilisation causing iron dysregulation, oxidative stress and bacterial death

3

4 J. Lueangsakulthai ${ }^{1,2}$, N. Jangpromma ${ }^{1,3}$, T. Temsiripong ${ }^{4}$, J.E. McKendrick ${ }^{5}$, W. Khunkitti ${ }^{6}$, S.E. Maddocks ${ }^{7}$ and S.

$5 \quad$ Klaynongsruang ${ }^{1,2}$

6

$7 \quad{ }^{1}$ Protein and Proteomics Research Center for Commercial and Industrial Purposes (ProCCI)

$8{ }^{2}$ Department of Biochemistry, Faculty of Science, Khon Kaen University, Khon Kaen, 40002, Thailand

$9{ }^{3}$ Office of the Dean, Faculty of Science, Khon Kaen University, Khon Kaen, 40002, Thailand

$10 \quad{ }^{4}$ Srirachamoda Co., Ltd. 383 Moo 4, Nongkham, Sriracha, Chonburi, 20230, Thailand

$11{ }^{5}$ Department of Chemistry, The University of Reading, Reading, RG6 6UR, United Kingdom

$12{ }^{6}$ Department of Pharmaceutical Technology, Faculty of Pharmaceutical Science, Khon Kaen University, Khon

13 Kaen, 40002, Thailand

$14{ }^{7}$ Department of Biomedical Sciences, Cardiff School of Health Science, Cardiff Metropolitan University, Cardiff,

15 CF5 2YB, United Kingdom

16

17 Correspondence

18 Sarah E. Maddocks, Department of Biomedical Sciences, Cardiff School of Health Science, Cardiff Metropolitan

19 University, Cardiff, CF5 2YB, United Kingdom.

20 Email: smaddocks@ cardiffmet.ac.uk

21 Sompong Klaynongsruang, Department of Biochemistry, Faculty of Science, Khon Kaen University, Khon Kaen, 22 40002, Thailand.

23 Email: somkly@kku.ac.th

25 Abstract

26 Aims: A novel antibacterial peptide from Crocodylus siamensis hemoglobin hydrolysate (CHHs) was characterised 27 for antimicrobial activity. 
Methods and Results: CHHs was hydrolysed for $2 \mathrm{~h}(2 \mathrm{~h}-\mathrm{CHH}), 4 \mathrm{~h}(4 \mathrm{~h}-\mathrm{CHH}), 6 \mathrm{~h}(6 \mathrm{~h}-\mathrm{CHH})$ and $8 \mathrm{~h}(8 \mathrm{~h}-\mathrm{CHH})$. 8h-CHH showed antibacterial activity against Escherichia coli, Staphylococcus aureus, Klebsiella pneumonia and Pseudomonas aeruginosa at concentrations of 20, 20, 20 and $10 \mathrm{mg} \mathrm{ml}^{-1}(\mathrm{w} / \mathrm{v})$, respectively. Fluorescent microscopy revealed that $8 \mathrm{~h}-\mathrm{CHH}$ had bactericidal activity against $E$. coli and $P$. aeruginosa. $\beta$-galactosidase assay supported by RT-qPCR demonstrated that $8 \mathrm{~h}-\mathrm{CHH}$ resulted in differential expression of genes involved in iron homeostasis $(f \operatorname{tn} A$ and $b f d)$ and oxidative stress $(\operatorname{sod} A, \operatorname{soxR}$ and $\operatorname{oxy} R)$. Siderophore assay indicated that $8 \mathrm{~h}-\mathrm{CHH}$ also impaired siderophore production with diminished expression of $p v d F$. This pattern of gene expression suggests that $8 \mathrm{~h}-\mathrm{CHH}$ triggers the release of free ferric ions in the cytoplasm. However, decreased expression of genes associated with the SOS response (recA and lexA) in combination with neutral comet revealed that no DNA damage was caused by $8 \mathrm{~h}-\mathrm{CHH}$. Membrane permeabilisation assay indicated that $8 \mathrm{~h}-\mathrm{CHH}$ caused membrane leakage thought to mediate the antibacterial and iron-stress responses observed, due to loss of regulated iron transport. The novel active peptide from 8h-CHH was determined as QAIIHNEKVQAHGKKVL (QL17), with $41 \%$ hydrophobicity and +2 net charge.

Conclusions: The QAIIHNEKVQAHGKKVL fragment of Crocodylus siamensis hemoglobin is antibacterial via a mechanism that likely relies on iron dysregulation and oxidative stress which results in bacterial death.

43 Significance and Impact of the Study: We have described for the first time, a novel peptide derived from 44 Crocodylus siamensis hemoglobin hydrolysate, that has the potential to be developed as a novel antimicrobial 45 peptide.

\section{$47 \quad$ Keywords}

48 Crocodylus siamensis, hemoglobin hydrolysate, antibacterial, peptide, oxidative stress genes, iron homeostasis 49 genes.

50

\section{Running headline}

52 Antibacterial peptide from C. siamensis hemoglobin

\section{Introduction}


Bacterial infections account for a significant proportion of the global infectious disease burden, and morbidity and mortality rates caused by infectious microbial agents pose serious public health concerns. This is exacerbated by

57 increasing resistance to antibiotics which is significant in an era where the development of new, synthetic antibacterial drugs lags the emergence of antimicrobial resistance (Mbah et al. 2012). It is therefore paramount to broaden the search for new antimicrobial substances, including the exploitation of novel sources where possible (Song et al. 2012). A growing area of research has begun to focus on protein hydrolysates of animal origin, such as goat whey protein hydrolyzed by treatment with alcalase, and which shows broad spectrum antibacterial activity (Osman et al. 2016). Similarly, an antibacterial peptide derived from acid extract of chicken (Gallus gallus) blood has efficacy against E. coli by a mechanism that results in toroidal pore formation and subsequent bacterial lysis (Vasilchenko et al. 2016). Furthermore, a peptic hemoglobin hydrolysate from bovine hemoglobin has also been shown to possess antibacterial activity (Froidevaux et al. 2001; Daoud et al. 2005; Arroume et al. 2006; Arroume et al. 2008; Adje et al. 2011). Whilst these areas of research are largely in their infancy, they provide a diverse, yet novel, means of informing the development of new peptide-based antimicrobial treatments. traumatic wounds that might be expected to be rife with infection from endogenous environmental bacteria, but this is not seen to be the case. $C$. siamensis (Siamese crocodile) hemoglobin constitutes the most abundant component in crocodile blood and has been long associated with a broad spectrum of biological activity, including antimicrobial (Srihongthong et al. 2012; Pakdeesuwan et al. 2017), antioxidant (Jandaruang et al. 2012; Srihongthong et al. 2012; Phosri et al. 2014; Maijaroen et al. 2016; Pakdeesuwan et al. 2017; Phosri et al. 2017) and anti-inflammatory activity (Phosri et al. 2014; Jangpromma et al. 2017; Phosri et al. 2017). Antibacterial activity has been attributed to peptides derived from $C$. siamensis hemoglobin and they are currently thought to be targeted to the bacterial surface (Srihongthong et al. 2012; Pakdeesuwan et al. 2017). However detailed studies of antimicrobial activity, mechanism of action and critical peptide sequences that mediate the observed activity are currently lacking.

79 blood $(\mathrm{CHH})$, hydrolysed for 2, 4, 6 and $8 \mathrm{~h}$ with pepsin, and to identify specific antimicrobial peptide fragments.

80 Minimum Inhibitory Concentration (MIC), Time-Killing kinetics and viability staining revealed both bactericidal and bacteriostatic activity or the crude, hydrolysed peptide cocktail. To establish a mechanism of activity, the effect

82 of CHHs on bacterial iron homeostasis was investigated using ftnA and $b f d$ linked reporter strains, and analysis of 
siderophore production. Due to the close association of iron homeostasis and oxidative stress, the expression levels of oxidative stress response genes $(\operatorname{oxy} R$, $\operatorname{sod} A$ and $\operatorname{sox} R)$ were also investigated but ruled out the inclusion of the SOS response genes or associated DNA damage as a mechanism of action. However, membrane permeability assay indicated the hemoglobin fragments disrupted the cell envelope; the active peptide was found to be positively charged and therefore likely functioned in a similar manner to cationic antimicrobial peptides.

\section{Materials and methods}

\section{Bacterial strains}

Escherichia coli (NCTC 10418), Pseudomonas aeruginosa (PAO1), Staphylococcus aureus (NCTC 13141), Klebsiella pneumonia (ATCC 13883), Bacillus subtilis were maintained on nutrient agar (NA) or nutrient broth (NB), aerobically at $37^{\circ} \mathrm{C}$ throughout the study, unless otherwise stated. E. coli MC4100, E. coli MC4100 ftnA-lacZ, E. coli MC4100 bfd-lacZ, E. coli H1914 $\Delta$ fur-ftnA-lacZ, E. coli H1914 $\Delta$ fur-bfd-lacZ carried stable chromosomal mutations that allowed them to be maintained on NB or NA as described above; these strains were provided by Prof. Simon Andrews (University of Reading).

\section{Hemoglobin extraction}

The extraction of hemoglobin from red blood cells (RBCs) was performed following the method of Srihongthong et al. (2012). The RBCs were washed three times with phosphate buffered saline (PBS) pH 7·0 and centrifuged at 3000 $\times \boldsymbol{g}$ for $5 \mathrm{~min}$ at $4^{\circ} \mathrm{C}$. Ice-cold distilled water with five-fold volume was added to the RBCs pellet, vigorously mixed and allowed to settle for $10 \mathrm{~min}$. After centrifugation at $10000 \times \mathrm{g}$ for $20 \mathrm{~min}$ at $4^{\circ} \mathrm{C}$ the supernatant was collected, lyophilized and stored at $-70^{\circ} \mathrm{C}$.

\section{Enzymatic hydrolysis}

Enzymatic hydrolysis was performed according to the method of Yu et al. (2006). Briefly, the hemoglobin solution was digested with pepsin (at $\mathrm{pH} 2 \cdot 0)$ using a ratio of enzyme to substrate $(1: 100 \mathrm{w} / \mathrm{w})$ at $37^{\circ} \mathrm{C}$ for $2,4,6$ and $8 \mathrm{~h}$ and boiled at $95^{\circ} \mathrm{C}$ for $10 \mathrm{~min}$ to inactivate the enzyme. The insoluble material was removed by centrifugation at $7168 \times$ $g$ for 20 min. The supernatant was collected and adjusted to $\mathrm{pH} 7 \cdot 0$ by addition of $1 \mathrm{M} \mathrm{HCl}$ or $1 \mathrm{M} \mathrm{NaOH}$. Finally the supernatant (hydrolysate) was lyophilized and stored at $-20^{\circ} \mathrm{C}$. 
112 Minimum inhibitory concentration (MIC) and time -killing assay (TKA)

113 The minimum inhibitory concentration (MIC) of CHHs was determined by microbroth dilution in a microtiter plate 114 assay system using a total volume of $110 \mu \mathrm{l}$ per well. Each well contained $10 \mu \mathrm{l}$ bacterial suspension (E. coli NCTC 11510418 , S. aureus, K. pneumoniae and P. aeruginosa; adjusted to OD $0 \cdot 1 \mathrm{~A}_{650}$ ) and $100 \mu 1$ of CHHs. Plates were 116 incubated for $24 \mathrm{~h}$ (MIC assay) or $9 \mathrm{~h}$ (TKA) at $37^{\circ} \mathrm{C}$. An end point reading was taken for MIC, and hourly readings 117 were taken for TKA $\left(\mathrm{A}_{650}\right)$ (Spectrostar ${ }^{\text {Nano }}$, BMG Labtech).

\section{Fluorescent microscopy using BacLight ${ }^{\mathrm{TM}}$ to assess bacterial viability}

120 Test microorganisms (E. coli NCTC 10418, S. aureus, K. pneumoniae, B. subtilis and P. aeruginosa) were incubated 121 for $16 \mathrm{~h}$ with 10 , or $20 \mathrm{mg} \mathrm{ml}^{-1} \mathrm{CHHs}$ (determined from MIC). Cultures were centrifuged at $9000 \times \mathrm{g}$ for $5 \mathrm{~min}$ and the supernatant was discarded. The cell pellets were re-suspended in $100 \mu 1 \mathrm{dH}_{2} \mathrm{O}$ containing SYTO9 and PI at a ratio of 2:1. Cells were incubated in the dark at room temperature for $45 \mathrm{~min}$ and $10 \mu 1$ transferred to a glass slide. Cells were visualized by fluorescent microscopy (Nikon eclipse 80i) using oil immersion and $\times 100$ lens. SYTO9 detection (viable cells) was used a $488 \mathrm{~nm}$ excitation and $520 \mathrm{~nm}$ emission filter. Propidium iodine (PI) detection (non-viable cells) was used $543 \mathrm{~nm}$ excitation and $572 \mathrm{~nm}$ emission filter.

\section{$\beta$-galactosidase assay}

129 Test microorganisms (E. coli MC4100, E. coli MC4100 ftnA-lacZ, E. coli MC4100 bfd-lacZ, E. coli H1914 $\Delta$ furftnA-lacZ, E. coli H1914Afur-bfd-lacZ) were cultured in $100 \mu 1 \mathrm{NB}$ in a 96-well microtiter plate until mid-log was reached. Then $100 \mu \mathrm{l}$ of 2, 4, 6 and $8 \mathrm{~h}-\mathrm{CHH}\left(20 \mathrm{mg} \mathrm{ml}^{-1}\right)$ was added to each well followed by an additional incubation for $1.5 \mathrm{~h}$ at $37^{\circ} \mathrm{C}$. Bacteria were permeabilised with buffer containing $60 \mathrm{mM} \mathrm{Na} 2 \mathrm{HPO}_{4} \cdot 7 \mathrm{H}_{2} \mathrm{O}, 40 \mathrm{mM}$ $\mathrm{NaH}_{2} \mathrm{PO}_{4} \cdot \mathrm{H}_{2} \mathrm{O}, 10 \mathrm{mM} \mathrm{KCl}, 1 \mathrm{mM} \mathrm{MgSO}{ }_{4} \cdot 7 \mathrm{H}_{2} \mathrm{O}, 50 \mathrm{mM} \beta$-mercaptoethanol, $0 \cdot 1 \%$ SDS and $4 \mu 1$ of chloroform 
141 CAS agarose diffusion assay followed the method of Schwyn and Neilands (1987). Pre-cultures of (E. coli MC4100,

142 E. coli NCTC 10418, S. aureus, K. pneumoniae, B. subtilis and P. aeruginosa) were equilibrated to OD 0·1 (A $\left.\mathrm{A}_{650}\right)$ 143 and supplemented with $20 \mathrm{mg} \mathrm{ml}^{-1}$ of 2, 4, 6 and 8h-CHH and $1 \mathrm{mM}$ DTPA. Treated cultures were incubated for a 144 further $24 \mathrm{~h}$ at $37^{\circ} \mathrm{C}$. After centrifuging at $9000 \times g$ for 3 min (Rotina $380 \mathrm{R}$ centrifuge; Hettich, Germany) $50 \mu 1$ 145 aliquots of the sample supernatant were added to wells bored into the center of Petri dishes filled with $25 \mathrm{ml}$ CAS 146 agarose agar. After incubating in the dark at room temperature for $2 \mathrm{~h}$, digital calipers were used to measure the 147 diameter $(\mathrm{mm})$ of the yellow diffusion zone diameters which is an indicator of siderophore production and the 148 reduction of ferric iron.

\section{RNA extraction and cDNA synthesis}

151 Total RNA was extracted from bacterial cells per the manufacturer's instructions using the SV Total RNA extraction 152 kit (Promega, USA). Total RNA concentration and purity were determined using Nanodrop ND-1000 spectrophotometer (Nanodrop Technologies, USA). RNA samples with an absorbance ratio at OD 260/280 between

$154 \quad 1 \cdot 8-2 \cdot 2$ and OD 260/230 $<2 \cdot 0$ were used for further analysis. For each sample, cDNA was synthesized using the 155 High-Capacity cDNA Reverse Transcription kit according to the manufacturer's instructions (Applied Biosystem 156 Inc).

\section{Reverse transcription - real time PCR (RT-qPCR) assay}

159 Primers used in this study are shown in Table 1. All PCR reactions were performed using 7500 Fast Real-Time PCR 160 System machine under following conditions: $15 \mathrm{~min}$ at $95^{\circ} \mathrm{C}$ and 40 cycles of $3 \mathrm{~s}$ at $95^{\circ} \mathrm{C}, 30 \mathrm{~s}$ at $68^{\circ} \mathrm{C}$ in 96 -well 161 clear optical reaction plates (Applied Biosystem, USA). The procedure ended by melt-curve ramping from 60 to $16295^{\circ} \mathrm{C}$ for 20 min to check the PCR specificity. All RT-qPCR reactions were carried out in biological and technical triplicate. A non-template control was also included in each run for each gene. 
Neutral comet assay was determined following the method of Solanky and Haydel (2012) with some modifications. Frosted microscope glass slides with a clear window were pre-coated by dipping in $1 \%$ agarose solution prepared with sterile water and were dried in an incubator at $40^{\circ} \mathrm{C}$ for $30 \mathrm{~min}$. E. coli MC4100 cultures were incubated with rotary agitation at $37^{\circ} \mathrm{C}$ until logarithmic phase of growth (OD $\sim 0 \cdot 1 ; \mathrm{A}_{600}$ ), and then diluted with $\mathrm{NB}$ broth to achieve a concentration of $\sim 10^{7} \mathrm{CFU} \mathrm{ml}{ }^{-1}$. The cells were collected by centrifugation $(9000 \times \mathrm{g}, 15 \mathrm{~min})$, washed

171 with $0.1 \times$ phosphate-buffered saline (PBS), and re-suspended in one of the following solutions: $1 \%$ TritonX-100; 5

$172 \mathrm{mM} \mathrm{H}_{2} \mathrm{O}_{2}$; deionized $\mathrm{H}_{2} \mathrm{O}$ and $8 \mathrm{~h}-\mathrm{CHH} 20 \mathrm{mg} \mathrm{ml}^{-1}$. Exposed cells were then incubated for $30 \mathrm{~min}$ at $37^{\circ} \mathrm{C}$.

173 After incubating the slide at $4^{\circ} \mathrm{C}$ for $10 \mathrm{~min}$ to allow the initial layer of agarose to cool, the coverslip was removed 174 and a subsequent agarose layer was added. The first layer consisted of $200 \mu 1$ of $0.5 \%$ agarose prepared in $0.1 \times$ PBS 175 and maintained at $55-60^{\circ} \mathrm{C}$ for $30 \mathrm{~min}$. For the second layer, $2 \mu 1$ of exposed cells was mixed thoroughly with 200 $\mu 1$ of $0.5 \%$ agarose solution and $100 \mu 1$ of this mixture was transferred to the slide. A third layer was consisted of 5

$177 \mu \mathrm{g} \mathrm{ml}^{-1} \mathrm{RNase} A$ and $1 \mathrm{mg} \mathrm{ml}^{-1}$ lysozyme in $0.5 \%$ agarose solution. Slides were refrigerated for $10 \mathrm{~min}$ at $4^{\circ} \mathrm{C}$ and 178 incubated for $30 \mathrm{~min}$ at $37^{\circ} \mathrm{C}$. Embedded cells were then lysed by immersing slides in a solution containing $2.5 \mathrm{M}$ $179 \mathrm{NaCl}, 100 \mathrm{mM}$ EDTA, $10 \mathrm{mM}$ Tris $\mathrm{pH} 10$ and 1\% TritonX-100 for $1 \mathrm{~h}$ at room temperature. Following lysis, slides were immersed in an enzyme digestion solution prepared with $2.5 \mathrm{M} \mathrm{NaCl}, 10 \mathrm{mM}$ EDTA, $10 \mathrm{mM}$ Tris pH 7.4, and $0.5 \mathrm{mg} \mathrm{ml}^{-1}$ of proteinase $\mathrm{K}$ for $2 \mathrm{~h}$ at $37^{\circ} \mathrm{C}$. Lysis and enzyme digestion steps were carried out in the dark to prevent light exposure. Slides were immersed in buffer containing $300 \mathrm{mM}$ sodium acetate and $100 \mathrm{mM}$ Tris, $\mathrm{pH} 9$ for 20 min. Slides were electrophoresed at $12 \mathrm{~V}$ for $50 \mathrm{~min}$. Following electrophoresis, slides were sequentially immersed in $1 \mathrm{M}$ ammonium acetate prepared in ethanol for $20 \mathrm{~min}$ and $75 \%$ ethanol for another $30 \mathrm{~min}$. Slides were then allowed to dry. Prior to staining, slides were pretreated with a freshly prepared solution of 5\% DMSO and $10 \mathrm{mM}$ $\mathrm{NaH}_{2} \mathrm{PO}_{4}$. While the slides were still wet, DNA was stained with $50 \mu \mathrm{l}$ of $1 \mu \mathrm{M}$ YOYO- 1 in $5 \%$ DMSO and 187 visualized using a Nikon eclipse 80i fluorescent microscope at 100× magnification with the appropriate filter set for YOYO-1 (excitation $491 \mathrm{~nm}$ and emission $509 \mathrm{~nm}$ ). Comets were imaged and comet lengths were measured using Volocity software version $5 \cdot 5$.

\section{Cytoplasmic membrane permeability assay}

192 Cytoplasmic membrane permeability assay was determined following the method of Chitemerere and 193 Mukanganyama (2014) with modifications. Briefly, bacteria (E. coli MC4100, P. aeruginosa, S. aureus) were grown 
to mid-exponential phase (OD 0.2-0.4; $\mathrm{A}_{650}$ ); $2 \mathrm{ml}$ were mixed with an equivalent volume of $1 \mu \mathrm{M}$ diSC3-5 dyes and incubated $1 \mathrm{~h}$, for maximal uptake of dye, then were collected by centrifugation ( $3000 \times g$ for $5 \mathrm{~min})$. Cells were wash and re-suspended in $2 \mathrm{ml}$ of buffer (5 mM HEPES, $\mathrm{pH} 7 \cdot 2,5 \mathrm{mM}$ glucose) and the absorbance was measured at an excitation wavelength of $622 \mathrm{~nm}$ and emission wavelength of $670 \mathrm{~nm}$. Afterward, $2 \mathrm{ml}$ of $100 \mathrm{mM} \mathrm{KCl}$ was added to equilibrate the cytoplasmic and external $\mathrm{K}^{+}$ion concentrations. Cells were mixed with and equal volume of sample then the fluorescence was monitored at an excitation wavelength of $622 \mathrm{~nm}$ and emission wavelength of 670 $\mathrm{nm}$ at $1 \mathrm{~h}$ intervals. Dye released with de-ionised water was used as a negative control.

\section{Amino acid sequence analysis}

The active fraction of 8h-CHH was selected and the contained peptides identified using LTQ Orbitrap XL Mass spectrometry employing the following search parameters: non-specified enzymatic cleavage with three possible missed cleavages, $+/-0.8$ Da mass tolerances for MS and MS/MS, a peptide mass tolerance of $+/-5 \mathrm{ppm}$, methionine oxidation and Gln->pyro-Glu (N-term Q) variable modification and monoisotopic mass. Data were additionally processed at the Mascot Server (http://www.matrixscience.com/) using MS/MS ion searches against SwissProt (current release).

\section{Statistical analysis}

211 Statistical analysis was performed using ANOVA and followed by Dunnett's test. Data are presented as mean \pm

212 SEM. A value of $P<0.05$ was accepted to be significant $(* P<0 \cdot 05$, ** $P<0 \cdot 01$, *** $P<0 \cdot 001)$.

\section{Results}

\section{Bacteriostatic and bactericidal effects of hemoglobin hydrolysate}

216 Bacteriostatic and bactericidal effects of hemoglobin hydrolysate were investigated by minimum inhibitory 217 concentration (MIC), time-killing assay (TKA) and fluorescent microscopy using BacLight ${ }^{\mathrm{TM}}$. The MIC was 218 determined using $2 \mathrm{~h}-\mathrm{CHH}, 4 \mathrm{~h}-\mathrm{CHH}, 6 \mathrm{~h}-\mathrm{CHH}$ and $8 \mathrm{~h}-\mathrm{CHH}$, and results are presented in Table 2. Gram-negative 219 microorganisms generally required higher concentrations of hydrolysed CHHs to inhibit growth. The results showed that all hydrolysed CHHs were antibacterial at concentrations of $20 \mathrm{mg} \mathrm{ml}^{-1}(\mathrm{w} / \mathrm{v})$ against E. coli and S. aureus. Furthermore, there was antibacterial activity for all CHHs at concentrations of $10 \mathrm{mg} \mathrm{ml}^{-1}$ (w/v) against $K$. 
pneumoniae and $P$. aeruginosa. Significantly, the dose required to inhibit growth decreased as the length of time that the hemoglobin was hydrolysed increased, suggesting that higher concentrations of shorter peptide fragments mediated the inhibitory activity. This was verified by TKA which indicated that $8 \mathrm{~h}-\mathrm{CHH}$ resulted in the highest percentage of bacterial death (Table 3). Samples analysed by BacLight ${ }^{\text {TM }}$ viability staining and fluorescent microscopy confirmed that $8 \mathrm{~h}-\mathrm{CHH}$ at a dose of 20 and $10 \mathrm{mg} \mathrm{ml}^{-1}$ caused bacterial death (E. coli NCTC 10418 and P. aeruginosa; Fig. 1a and 1b, respectively). At lower doses and shorter hydrolyze times, $\mathrm{CHH}$ treatments tended to be bacteriostatic rather than bactericidal. Both mechanisms were investigated as described below.

Hemoglobin hydrolysate alters bacterial iron homeostasis and causes oxidative stress without inducing irreversible DNA-damage or the SOS response The $\beta$-galactosidase assay demonstrated that $2 \mathrm{~h}-\mathrm{CHH}, 4 \mathrm{~h}-\mathrm{CHH}, 6 \mathrm{~h}-\mathrm{CHH}$ and $8 \mathrm{~h}-\mathrm{CHH}$ at $20 \mathrm{mg} \mathrm{ml}^{-1}$ decreased the expression of $f t n A$ while increasing the expression of $b f d$, under iron rich conditions (Fig. 2). Decreased expression of $f t n A$ is indicative of iron restriction whereas increased expression of $b f d$ is affiliated with iron repletion and is known to have a role in haem-iron handling. The expression profile was not altered in a $\Delta$ fur background suggesting that the dysregulated expression of $f t n A$ and $b f d$ was not the result of Fur-dependent iron-mediated regulation (Fig. 2). However, CASD assay indicated that CHHs decreased the production of siderophores (Fig. 3) and following treatment with $8 \mathrm{~h}-\mathrm{CHH}$, the expression of $p v d F$ (associated with siderophore synthesis) also significantly decreased $(P<0.05)$ (Fig. 4b) suggesting some degree of altered iron homeostasis. Bacterial iron metabolism and oxidative stress are inextricably linked; RT-qPCR demonstrated that following treatment with $8 \mathrm{~h}-\mathrm{CHH}$, the expression of oxidative stress response genes $\operatorname{sodA}$ and $\operatorname{sox} R$ significantly increased while the expression of $\operatorname{oxy} R$ decreased (Fig. 4a). Oxidative stress is correlated with DNA damage and subsequent induction of the SOS system of repair. However, the expression of recA was diminished and lexA

244 unchanged following treatment with 8h-CHH suggesting that the SOS response was not initiated (Fig. 4c). 245 Therefore, the dysregulated iron homeostasis observed might be mediated by transcriptional responses associated with oxidative stress, rather than in response to environmental iron availability. 
Neutral Comet Assay verified that $\mathrm{CHH}$ did not cause DNA damage. Treatment with 1\% TritonX-100 and $5 \mathrm{mM}$ $\mathrm{H}_{2} \mathrm{O}_{2}$ (positive controls) produced an increase in comet length, and therefore DNA degradation, relative to the negative control (DI sterilized water). Exposure of E. coli $\mathrm{MC} 4100$ to $1 \%$ TritonX-100 and $5 \mathrm{mM} \mathrm{H}_{2} \mathrm{O}_{2}$ for 30 min

252 increased the comet length values of $49 \cdot 79 \mu \mathrm{m}$ and $21 \cdot 12 \mu \mathrm{m}$, respectively. Meanwhile the exposure of $8 \mathrm{~h}-\mathrm{CHH}$ resulted in comet length values of $11.24 \mu \mathrm{m}$ and the negative control, $10.78 \mu \mathrm{m}$ as shown in Table 4 . The $1 \%$

254 TritonX-100 also yielded higher a comet length value, demonstrating higher DNA double strand break (DSB) levels while DNA double strand break wasn't caused by 8h-CHH upon exposure in bacterial cells.

\section{Hemoglobin hydrolysate causes bacterial membrane leakage}

Many short peptides aggregate in bacterial membranes resulting in a loss of integrity, such loss of integrity allows influx and efflux of various solutes and ions, including metal ions such as iron. It was hypothesized that membrane disruption might underpin the iron homeostatic dysregulation and concurrent oxidative stress response described above. Indeed, results from cytoplasmic membrane permeability assay, showed a gradual increase of diSC3-5 dye release over time in the presence of $8 \mathrm{~h}-\mathrm{CHH}$ as well as in the presence of the $1 \%$ TritonX-100 positive control (Fig. 5a, 5b and 5c). Similarly, diSC3-5 was released from all test microorganisms following exposure to $8 \mathrm{~h}-\mathrm{CHH}$ for 60 min (Fig. 5). The effect was most marked for the Gram-negative test microorganisms (E. coli and P. aeruginosa) indicating that $8 \mathrm{~h}-\mathrm{CHH}$ can permeabilise the cell envelope more effectively than that of Gram-positive microorganisms (S. aureus).

\section{Active peptide was identified by LTQ Orbitrap XL mass spectrometry}

269 To establish the identity of the active CHH peptide, the primary sequence was determined using LTQ Orbitrap XL 270 mass spectrometry. As the most active $\mathrm{CHH}$, the amino acid sequences of $8 \mathrm{~h}-\mathrm{CHH}$ was determined as 271 QAIIHNEKVQAHGKKVL (QL17) corresponding to a molecular mass of 1895.07 Da. The obtained sequence was 272 uploaded to the antimicrobial database (http://aps.unmc.edu/AP/main.php) and the protein databank 273 (https://www.ncbi.nlm.nih.gov) for further characterization. As shown in Table 5, antibacterial peptide QL 17 had 274 hydrophobicity values of approximately $41 \%$, with a net charge of +2 . Alignment of the amino acid sequences of the peptide fragments with $C$. siamensis hemoglobin indicated the antibacterial peptide originated from the $\beta$-subunit of 
C. siamensis hemoglobin. The short length and positive charge of the peptide indicates that it might aggregate in the bacterial cell envelope in much the same way as cationic antimicrobial peptides.

\section{Discussion}

Protein hydrolysates are gaining popularity for their potential therapeutic effects due to demonstrable efficacy and low toxicity. This study used MIC, time-killing kinetics and viability staining to ascribe antimicrobial activity to hemoglobin hydrolysate from $C$. siamensis. CHHs were either bacteriostatic or bactericidal depending on the species of bacteria, dose and length of hydrolyzed time. Longer hydrolysis times correlated with higher inhibition of growth, with $8 \mathrm{~h}-\mathrm{CHH}$ proving to be the most efficacious. The antibacterial mechanism was investigated with focus on iron homeostasis and oxidative stress which in numerous pathogens is associated with host haem-iron availability.

The expression of $f t n A$ was increased and that of both $b f d$ and $p v d F$ decreased following exposure to $8 \mathrm{~h}$ -

$287 \mathrm{CHH}$. Under iron repleted conditions expression of $f t n A$ and $b f d$ is ordinarily repressed via a process relying on the 288 ferric uptake regulator (Fur). The observed expression profile was no concordant with typical iron-Fur regulation which was verified using a $\Delta f u r$ background, which showed the same expression profile as the wild-type background. However, differential expression of $f \operatorname{tn} A, b f d$ and $p v d F$ also occurs in response to oxidative stress, which is closely allied to iron homeostasis (Zheng et al. 1999). Quantitative analysis of the expression of soxR and oxyR indicated differential expression in response to $\mathrm{CHH}$-treatment akin to that observed during oxidative stress, indicating that $\mathrm{CHH}$ induced a state of oxidative stress in the microorganisms tested.

Uncontrolled oxidative stress results in widespread lipid, protein and DNA damage (Gault et al. 2016). If DNA damage becomes too great, the bacterial SOS system is activated. LexA is the master regulator of the SOS response; under normal conditions it represses the expression of genes encoding several DNA repair proteins, including recA. LexA has a negative auto-regulatory function and when the SOS response is triggered, increased 298 levels of lexA are also produced which ultimately serves as a negative feedback mechanism to switch of the SOS 299 response once rescue is achieved (Michel 2005). In this study, the expression of lexA was unchanged and recA decreased following treatment with $\mathrm{CHH}$ indicating that while oxidative stress occurred it was below the threshold 301 to necessary to induce the SOS system. This was verified by the absence of DNA damage (a key signal for SOS induction) observed by neutral comet assay. 
The bacterial response to outer membrane stress is distinct to the oxidative stress and SOS response, but triggers several stress-associated, damage repair pathways to maintain membrane integrity and prevent influx/efflux between the cytoplasm and external environment. Cationic antimicrobial peptides are well known to disrupt the bacterial cell envelope by aggregating to form pores within the membrane. Ordinarily this causes catastrophic damage resulting in bacterial death by lysis. Analysis of membrane integrity following treatment with $\mathrm{CHH}$ indicated that 8h-CHH could permeabilise E. coli, P. aeruginosa and S. aureus (Chitemerere and Mukanganyama 2014). The active peptide from $8 \mathrm{~h}-\mathrm{CHH}$ was identified using LTQ-Orbitrap XL mass spectrometry and the sequence determined as QAIIHNEKVQAHGKKVL (QL17) corresponding to a molecular mass of 1895.07 Da. The peptide QL17 had hydrophobicity values of about $41 \%$, together with a net charge of +2 . Given its positive charge, this fragment is hypothesized to aggregates within the bacterial membrane, in the same way as cationic antimicrobial peptides (Sato and Feix 2006). It is known that antimicrobial peptides positive charge combined with hydrophobicity is critical for partitioning of the peptide into the bacterial cell membrane (Pata et al. 2011). antibacterial peptide originated from the $\beta$-subunit of $C$. siamensis hemoglobin. This result agrees with Arroume $e t$ al. (2008), who reported that antimicrobial products derived from hemoglobin hydrolysis are cleaved from the $\alpha$ and $\beta$-subunits. These products mostly consist of $\sim 15-30$ amino acid residues and have a molecular weight $<10$ kDa. Of note, was the correlation between length of hydrolysis time and antimicrobial activity. As expected, hemoglobin hydrolysed for longer periods of time comprised a higher concentration of small peptide fragments, which in turn exhibited better antimicrobial efficacy, highlighting the importance of peptide fragment size for activity.

Taken collectively, the data derived from this study indicates that the hemoglobin of $C$. siamensis can be 324 hydrolyzed to produce a novel antimicrobial peptide that at high concentrations mediates bacterial death by 325 aggregating in the cell envelope and damaging membrane integrity. The consequent influx of exogenous material combined with an efflux of cytoplasmic content likely underpins the dysregulation of iron homeostasis and 327 concurrent oxidative stress. Whilst the potential to utilise antimicrobial peptides derived from hemoglobin warrants 328 further study, blood derived from C. siamensis is currently a waste-product of farming. Therefore, with larger studies drawn from this exploratory research, it could instead be developed as a natural or synthetic antimicrobial peptide, engineered to ensure maximum efficacy and minimal toxicity. 


\section{Acknowledgements}

333 This research was financial supported by the Royal Golden Jubilee Ph.D. program (RGJ-PHD program), Grant No. $334 \mathrm{PhD}$ 0258/2552 and the Newton Fund (British Council). We also grateful to the Protein and Proteomics Research Center for Commercial and Industrial Purposes (ProCCI), Department of Biochemistry, Faculty of Science, Khon

336 Kaen University, Department of Pharmaceutical Technology, Faculty of Pharmaceutical Science, Khon Kaen University, Department of chemistry, The University of Reading, United Kingdom and Department of Biomedical laboratory facilities. Additionally, we would like to thank Srirachamoda Co., Ltd., Chon Buri, Thailand for supplying crocodile blood samples. We also thank Prof. Simon Andrews (University of Reading) for providing $E$. coli strains.

\section{Conflict of Interest}

344 The authors confirm that this article content has no conflicts of interest.

\section{References}

Adje, E.Y., Balti, R., Kouach, M., Dhulster, P., Guillochon, D. and Arroume, N.N. (2011) Obtaining antimicrobial peptides by controlled peptic hydrolysis of bovine hemoglobin. Int J Biol Macromol 49, 143-153.

Ali, R., Lutfullah, G., Khan, A.A. and Rashid, M.I. (2013) Analysis of oxygen affinity in aquatic amphibian; homology modelling of the major Haemoglobin component HbA1 from the African clawed frog (Xenopus laevis, Anura). Int J Bioinform Res Appl 9, 449-461.

Arroume, N.N., Delval, V.D., Miloudi, K., Daoud, R., Krier, F., Kouach, M., Briand, G. and Guillochon, D. (2006) Isolation and characterization of four antibacterial peptides from bovine hemoglobin. Peptides 27, 20822089.

Arroume, N.N., Delval, V.D., Adje, E.Y., Traisnel, J., Krier, F., Mary, P., Kouach, M., Briand, G. and Guillochon, D. (2008) Bovine hemoglobin: An attractive source of antibacterial peptides. Peptides 29, 969-977. target for plant products. BMC Complement Altern Med 14, 278. 
Daoud, R., Dubois, V., Dodita, L.B., Arroume, N.N., Krier, F., Chihib, N.E., Mary, P., Kouach, M., Briand, G. and Guillochon, D. (2005) New antibacterial peptide derived from bovine hemoglobin. Peptides 26, 713-719.

Froidevaux, R., Kriera, F., Arroume, N.N., Marko, D.V., Kosciarz, E., Ruckebusch, C., Dhulster P. and Guillochon D. (2001) Antibacterial activity of a pepsin-derived bovine hemoglobin fragment. FEBS Letters 491, 159163.

Gault, M., Effantin, G. and Rodrigue, A. (2016) Ni exposure impacts the pool of free Fe and modifies DNA supercoiling via metal induced oxidative stress in Escherichia coli K-12. Free Radic Biol Med 97, 351361.

Jandaruang, J., Siritapetawee, J., Thumanu, K., Songsiriritthigul, C., Krittanai, C., Daduang, S., Dhiravisit, A. and Thammasirirak, S. (2012) The effects of temperature and $\mathrm{pH}$ on secondary structure and antioxidant activity of Crocodylus siamensis hemoglobin. Protein J 31, 43-50.

Jangpromma, N., Poolperm, N., Pornsri, K., Anwised, P., Kabbua, T., Phosri, S., Daduang, S. and Klaynongsruang, S. (2017) Proteomics profiling and inflammatory factor gene expression in LPS-stimulated RAW 264.7 cells treated with Crocodylus siamensis hemoglobin. Chiang Mai J Sci 44, 1-16.

Maijaroen, S., Anwised, P., Klaynongsruang, S., Daduang, S. and Boonmee, A. (2016) Comparison of recombinant $\alpha$-hemoglobin from Crocodylus siamensis expressed in different cloning vectors and their biological properties. Protein Expr Purif 118, 55-63.

Mbah, J.A., Ngemenya, M.N., Abawah, A.L., Babiaka, S.B., Nubed, L.N., Nyongbela, K.D., Lemuh, N.D. and Efange, S.M.N. (2012) Bioassay-guided discovery of antibacterial agents: in vitro screening of Peperomia vulcanica, Peperomia fernandopoioana and Scleria striatinux. Ann Clin Microbiol Antimicrob 11, 10.

Michel, B. (2005) After 30 years of study, the bacterial SOS response still surprises us. PLoS Biol 3, 1174-1176.

Miller, J.H. Experiments in molecular genetics. Cold Spring Harbor Laboratory, NY; 1972. pp. 352-355.

Osman, A., Goda, H.A., Hamid, M.A., Badran, S.M. and Otte, J. (2016) Antibacterial peptides generated by alcalase hydrolysis of goat whey. LWT - Food Sci Technol 65, 480-486.

Pakdeesuwan, A., Araki, T., Daduang, S., Payoungkiattikun, W., Jangpromma, N. and Klaynongsruang, S. (2017) In Vivo wound healing activity of crocodile (Crocodylus siamensis) hemoglobin and evaluation of antibacterial and antioxidant properties of hemoglobin and hemoglobin hydrolysate. J Microbiol Biotechnol 27, 26-35. 
Pata, S., Yaraksa, N., Daduang, S., Temsiripong, Y., Svasti, J., Araki, T. and Thammasiriraka, S. (2011) Characterization of the novel antibacterial peptide Leucrocin from crocodile (Crocodylus siamensis) white blood cell extracts. Dev Comp Immunol 35, 545-553.

Phosri, S., Mahakunakorn, P., Lueangsakulthai, J., Jangpromma, N., Swatsitang, P., Daduang, S., Dhiravisit, A. and Thammasirirak, S. (2014) An investigation of antioxidant and anti-inflammatory activities from blood components of crocodile (Crocodylus siamensis). Protein J 33, 484-492.

Phosri, S., Jangpromma, N., Patramanon, R., Kongyingyoes, B., Mahakunakorn, P. and Klaynongsruang, S. (2017). Protective effect of crocodile hemoglobin and whole blood against hydrogen peroxide-induced oxidative damage in Human Lung Fibroblasts (MRC-5) and inflammation in mice. Inflammation 40, $205-220$.

Sato, H. and Feix, J.B. (2006) Peptide-membrane interactions and mechanisms of membrane destruction by amphipathic $\alpha$-helical antimicrobial peptides. Biochimica et Biophysica Acta 1758, 1245-1256.

Schwyn, B. and Neilands, J.B. (1987) Universal chemical assay for the detection and determination of siderophores. Anal Biochem 160, 47-56.

Solanky, D. and Haydel, S.E. (2012) Adaptation of the neutral bacterial comet assay to assess antimicrobialmediated DNA double-strand breaks in Escherichia coli. J Microbiol Methods 91, 257-261.

Song, R., Wei, R.B., Luo, H.Y. and Wang, D.F. (2012) Isolation and characterization of an antibacterial peptide fraction from the pepsin hydrolysate of Half-Fin Anchovy (Setipinna taty). Molecules 17, 2980-2991.

Srihongthong, S., Pakdeesuwan, A., Daduang, S., Araki, T., Dhiravisit, A. and Thammasirirak, S. (2012) Complete amino acid sequence of globin chains and biological activity of fragmented crocodile hemoglobin (Crocodylus siamensis). Protein J 31, 466-476.

Vasilchenko, A.S., Rogozhin, E.A., Vasilchenko, A.V., Kartashova, O.L. and Sycheva, M.V. (2016) Novel haemoglobin-derived antimicrobial peptides from chicken (Gallus gallus) blood: purification, structural aspects and biological activity. J Appl Microbiol 121, 1546-1557.

Yu, Y., Hu, J., Miyaguchi, Y., Bai, X., Du, Y. and Lin, B. (2006) Isolation and characterization of angiotensin Iconverting enzyme inhibitory peptides derived from porcine hemoglobin. Peptides 27, 2950-2956.

Zheng, M., Doan, B., Schneider, T.D. and Storz, G. (1999) OxyR and SoxRS regulation of fur. J Bacteriol 181, 4639-4643. 


\begin{tabular}{|c|c|c|c|c|c|c|}
\hline Species & $\begin{array}{c}\text { Gene } \\
\text { names }\end{array}$ & $\begin{array}{c}\text { GeneBank } \\
\text { accession no. }\end{array}$ & Region & $\begin{array}{l}\text { Product } \\
\text { size (bp) }\end{array}$ & Forward primer $(5 \rightarrow 3)$ & Reverse primer $\left(5^{\prime} \rightarrow 3^{\prime}\right)$ \\
\hline \multirow[t]{6}{*}{ E. coli } & oxyR & HG738867 & $\begin{array}{c}2620691 . .2 \\
621608\end{array}$ & 197 & $\begin{array}{l}\text { CCCCGGCTTCAAAACAGAAA } \\
\end{array}$ & GCTGGTGAAAGAGAGCGAAC \\
\hline & $\operatorname{sod} A$ & & $\begin{array}{c}2678668 . .2 \\
679288\end{array}$ & 187 & CGAAGTCACGTTCGATAGCC & CTGCCAGAATTTGCCAACCT \\
\hline & soxR & & $\begin{array}{c}4163425 . .4 \\
163889\end{array}$ & 172 & CAGCGGCGATATAAACGTGA & CCAACTCTTCTCGCCATTGG \\
\hline & $\operatorname{rec} A$ & & $\begin{array}{c}3960012 . .3 \\
961073\end{array}$ & 173 & GAAGAACAAAATCGCTGCGC & CATTCGCTTTACCCTGACCG \\
\hline & $\operatorname{lex} A$ & & $\begin{array}{c}4143071 . .4 \\
143679\end{array}$ & 158 & GCAGGAAGAGGAAGAAGGGT & CTTTCATCGACATCCCGCTG \\
\hline & $r p o D$ & BA000007 & $\begin{array}{c}3952578.3 \\
954419\end{array}$ & 220 & TTCGTACGCAAGAACGTCTG & AGGCCGGTTTCTTCTTCAAT \\
\hline \multirow[t]{2}{*}{ P. aeruginosa } & $p v d F$ & NC_002516 & $\begin{array}{c}2652230 . .2 \\
653057\end{array}$ & 181 & CGTACCAGCTCATCGAGGAT & AGACCCTGAACGACCTCTTG \\
\hline & $r p o D$ & & $\begin{array}{c}634371 . . \\
636224\end{array}$ & 186 & GGGTCACATCGAACTGCTTG & TCATCGAGGACTCCACCATG \\
\hline
\end{tabular}

424

425 Table 2 The MIC values of sample CHHs

426

427

428

\begin{tabular}{|c|c|c|c|c|c|c|c|c|}
\hline & E.coli & K.pneumoniae & P.aeruginosa & S.aureus & E.coli & K.pneumoniae & P.aeruginosa & S.aureus \\
\hline 2h-CHH & 20 & 20 & 10 & 20 & $33 \cdot 33 * * * \pm 0 \cdot 003$ & $57 \cdot 14 * * * \pm 0 \cdot 015$ & $34 \cdot 11 * * * \pm 0 \cdot 004$ & $38 \cdot 87 * * * \pm 0 \cdot 005$ \\
\hline $4 \mathrm{~h}-\mathrm{CHH}$ & 20 & 10 & 10 & 10 & $21 \cdot 74 * * * \pm 0 \cdot 025$ & $34 \cdot 29 * * * \pm 0 \cdot 002$ & $25 \cdot 10^{* * * * \pm 0} \pm 002$ & $21 \cdot 11 * * * \pm 0 \cdot 031$ \\
\hline 6h-CHH & 20 & 10 & 10 & 20 & $37 \cdot 86^{* * *} \pm 0 \cdot 007$ & $45 \cdot 14 * * * \pm 0 \cdot 008$ & $35 \cdot 03 * * * \pm 0 \cdot 008$ & $25 \cdot 53 * * * \pm 0 \cdot 020$ \\
\hline $8 \mathrm{~h}-\mathrm{CHH}$ & 20 & 20 & 10 & 20 & $24 \cdot 64 * * * \pm 0 \cdot 003$ & $41 \cdot 10^{* * * \pm 0} \pm 113$ & $44 \cdot 61 * * * \pm 0 \cdot 020$ & $31 \cdot 20 * * * \pm 0 \cdot 195$ \\
\hline
\end{tabular}

431 
Table 3 Time-killing assay (TKA) of sample CHHs

436

437

\begin{tabular}{|c|c|c|c|c|}
\hline \multirow{2}{*}{ Sample } & \multicolumn{4}{|c|}{ \%Growth inhibition at $9 \mathrm{~h}$ intervals } \\
\hline & E.coli & K.pneumoniae & P.aeruginosa & S.aureus \\
\hline 2h-CHH & $48 \cdot 07 * * * \pm 0 \cdot 001$ & $3 \cdot 21 * * * \pm 0 \cdot 011$ & $6 \cdot 07 * * * \pm 0 \cdot 004$ & $31 \cdot 23 * * * \pm 0 \cdot 006$ \\
\hline 4h-CHH & $55 \cdot 64 * * * \pm 0.007$ & $4 \cdot 06^{* * *} \pm 0 \cdot 002$ & $4 \cdot 98 * * * \pm 0.007$ & $56 \cdot 31 * * * \pm 0 \cdot 007$ \\
\hline 6h-CHH & $73 \cdot 37 * * * \pm 0 \cdot 001$ & $0 \cdot 06 \pm 0 \cdot 002$ & $10 \cdot 65^{* * *} \pm 0 \cdot 011$ & $33 \cdot 23 * * * \pm 0 \cdot 013$ \\
\hline 8h-CHH & $48 \cdot 54 * * * \pm 0 \cdot 020$ & $12 \cdot 00 * * * \pm 0 \cdot 015$ & $21 \cdot 73 * * * \pm 0 \cdot 004$ & $17 \cdot 88^{* * * \pm 0} \pm 115$ \\
\hline
\end{tabular}

444

*** denotes $P<0 \cdot 001$. Data expressed as a mean \pm SEM of 3 independent experiments. Significance was measured using ANOVA followed by Dunnett's test.

445

446 Table 4 Neutral bacterial comet assay following E.coli exposure to $1 \%$ TritonX-100, $5 \mathrm{mM} \mathrm{H}_{2} \mathrm{O}_{2}$, 8h-CHH and DI water.

447

448

449

450

451

452

E.coli treated with

\begin{tabular}{ccccc}
\hline & \multicolumn{4}{c}{ E.coli treated with } \\
& $1 \%(\mathrm{v} / \mathrm{v})$ & $5 \mathrm{mM} \mathrm{H}_{2} \mathrm{O}_{2}$ & $8 \mathrm{~h}-\mathrm{CHH}$ & DI water \\
\hline $\begin{array}{c}\text { TritonX-100 } \\
\text { length } \\
\text { values }(\mu \mathrm{m})\end{array}$ & $49 \cdot 79 * *{ }^{*} \pm 0 \cdot 002$ & $21 \cdot 12 * * * \pm 0 \cdot 010$ & $11 \cdot 24 \pm 0 \cdot 014$ & $10 \cdot 78 \pm 0 \cdot 009$ \\
\hline
\end{tabular}

453 
454 Table 5 Structural characteristics of the antibacterial peptide from $8 \mathrm{~h}-\mathrm{CHH}$

\begin{tabular}{|c|c|c|c|c|c|}
\hline Property & Peptide sequence & Hydrolysate & $\begin{array}{l}\text { \%Hydropho- } \\
\text { bicity }\end{array}$ & $\begin{array}{c}\text { Net } \\
\text { charge }\end{array}$ & Sequence alignment \\
\hline Antibacterial & $\begin{array}{c}\text { QAIIHNEKVQAHGKKVL } \\
\text { (QL17) }\end{array}$ & $8 \mathrm{~h}-\mathrm{CHH}$ & $41 \%$ & +2 & $\begin{array}{c}\text { C. siamensis } \mathrm{Hb} \\
\beta \text {-subunit } \\
\text { (position 53-69) }\end{array}$ \\
\hline
\end{tabular}

455

456

457

458

459

460

461

462

463

464

465

466

467

468

469

470

471

472

473

474

475

476 
478 Figure 1 Representative images of Live and Dead staining assay (BacLight ${ }^{\mathrm{TM}}$ Fluoresent microscopy), red coloured 479 cells are dead cells and green coloured cells are live cells, showed the bactericidal effect of $8 \mathrm{~h}-\mathrm{CHH}$ at a dose of 20 and $10 \mathrm{mg} \mathrm{ml}^{-1}$ against (a) E.coli and (b) P.aeruginosa PAO1, respectively.

481

Figure $2 \beta$-galactosidase assay. Expression of $f \operatorname{tn} A$ and $b f d$ in response to treatment with CHHs does not exhibit iron-dependent expression in a wild-type or $\Delta f u r$ background. Each bar represents the mean \pm SEM $(\mathrm{n}=3)$. *** significant at $P<0 \cdot 001$.

Figure 3 The effect of CHHs on siderophore production by CASD assay. Sample CHHs decreased the production of siderophore from all of bacterial strains over a time frame of $2 \mathrm{~h}$. Each bar represents the mean \pm SEM $(\mathrm{n}=3)$. **** significant at $P<0 \cdot 001$.

Figure 4 Effect of 8h-CHH on gene expression levels in E.coli and P.aeruginosa were analyzed by real time PCR (RT-qPCR). (a) A fold change gene expression of $\operatorname{oxy} R$, $\operatorname{sod} A$ and $\operatorname{sox} R$ were validated for oxidative stress response. (n=3). *significant at $P<0 \cdot 05, * *$ significant at $P<0.01$ and $* * *$ significant at $P<0 \cdot 001$.

Figure 5 Measurement of 3’3 dipropylthiadicarbocyanine (diSC3-5) dye release overtime from (a) E.coli, (b) and negative control Deionize water (DI). 